\title{
PENINGKATAN KEMAMPUAN MENJELASKAN PENTINGNYA KEUTUHAN NKRI MELALUI PEMBELAJARAN TALKING STICKSISWA KELAS V SDN 2 PATARSELAMAT
}

\author{
Maria Ulfa \\ SDN 2 Patarselamat Sangkapura Gresik \\ Email :m_ulfa59@yahoo.com
}

\begin{abstract}
One of the realities in education that will be discussed here is that the process of achieving learning in SDN 2 Patarselamat still uses the old paradigm, even though the current curriculum has evolved. So as not to rule out the possibility of learning outcomes achieved by students seem monotonous because it only memorizes facts and the teacher is seen as the main source in learning. One of the learning outcomes obtained is the Citizenship Education subject for class $\mathrm{V}$ which shows results that do not meet the minimum completeness. In this case for Citizenship Education, Patarselamat 2 Primary School sets KKM 70. While the class is declared a complete classic if the number of students who have finished learning individually reaches $>85 \%$. From the results of the study found that the average value in the first cycle 69.5 and $70 \%$ mastery of learning and in the second cycle increased by 80 and $95 \%$ mastery learning. Referring to the action hypothesis proposed in this class action research, it can be concluded that: there is an increase in the ability to explain the importance of the integrity of the Unitary State of Indonesia through learning the Talking Stick to fifth grade students at SDN 2 Patarselamat in the academic year 2017/2018.
\end{abstract}

Keywords: Ability to explain, integrity of the Republic of Indonesia, Talking Stick

\begin{abstract}
Abstrak: Salah satu realitas di bidang pendidikan yang akan dibicarakan di sini ialah bahwa proses pencapaian pembelajaran di SDN 2 Patarselamat masih menggunakan paradigma lama, meskipun kurikulum saat ini telah berkembang. Sehingga tidak mengesampingkan kemungkinan hasil belajar yang dicapai oleh siswa terkesan monoton karena hanya menghafal fakta dan guru dipandang sebagai sumber utama dalam pembelajaran. Salah satu hasil pembelajaran yang diperoleh adalah mata pelajaran Pendidikan Kewarganegaraan untuk kelas V yang menunjukkan hasil yang belum memenuhi kelengkapan minimal. Dalam hal ini untuk Pendidikan Kewarganegaraan, Sekolah Dasar 2 Patarselamat menetapkan KKM 70. Sementara kelas dinyatakan klasik lengkap jika jumlah siswa yang telah selesai belajar secara individual mencapai $>85 \%$. Dari hasil
\end{abstract}


penelitian ditemukan bahwa nilai rata-rata pada siklus pertama 69,5 dan 70\% penguasaan pembelajaran dan pada siklus II meningkat sebesar 80 dan penguasaan belajar 95\%. Mengacu pada hipotesis tindakan yang diajukan dalam penelitian tindakan kelas ini, dapat disimpulkan bahwa: ada peningkatan kemampuan untuk menjelaskan pentingnya integritas Negara Kesatuan Indonesia melalui pembelajaran Tongkat Bicara pada siswa kelas lima di SDN 2 Patarselamat pada tahun akademik 2017/2018.

Kata kunci: Kemampuan menjelaskan, integritas Republik Indonesia, Talking Stick.

\section{Pendahuluan}

Tantangan terhadap peningkatan mutu, relevansi, dan efektivitas pendidikan sebagai tuntutan nasional sejalan dengan perkembangan dan kemajuan masyarakat, berimplikasi secara nyata dalam program pendidikan dan kurikulum sekolah. Tujuan dari program kurikulum dapat tercapai dengan baik jika programnya didesain secara jelas dan aplikatif. Dalam hubungan inilah para guru dituntut untuk memiliki kemampuan mendesain programnya dan sekaligus menentukan strategi instruksional yang harus ditempuh. "Para guru harus memiliki keterampilan memilih dan menggunakan metode mengajar untuk diterapkan dalam sistem pembelajaran yang efektif'. ${ }^{1}$

Oleh karena itu, guru dipandang sebagai agen modernisasi dalam segala bidang. Usaha utama yang dapat dilakukan oleh guru adalah melalui program pendidikan bagi para siswa.

Dalam melakukan usaha pencapaian tujuan pendidikan di sekolah tersebut, guru berperan penting dalam menggunakan metode dan cara untuk mencapai hasil belajar yang optimal. Untuk mencapai tujuan tersebut sangat didukung oleh strategi yang digunakan guru dalam proses belajar mengajar.

Menurut Usman mengatakan bahwa proses belajar mengajar merupakan suatu proses yang mengandung serangkaian perbuatan guru dan siswa atas dasar hubungan timbal balik yang berlangsung dalam situasi edukatif untuk mencapai tujuan tertentu. Interaksi dan hubungan timbal balik antara guru dan siswa itu merupakan syarat utama bagi berlangsungnya proses belajar mengajar. ${ }^{2}$

Berdasarkan pendapat tersebut Kusaeri, mengatakan bahwa guru sebagai pelaksana terdepan, harus dapat mengantisipasi perkembangan ini, dengan memberikan materi pembelajaran dengan strategi pengajaran yang diinginkan

1 O. Hamalik, Proses Belajar Mengajar (Jakarta : PT. Bumi Aksara, 2001), 26.

2 Usman, Proses Belajar Mengajar (Jakarta: Prestasi Pustaka Raya, 2002), 144. 
Peningkatan Kemampuan Menjelaskan Pentingnya Keutuhan NKRI

Melalui Pembelajaran Talking Stick Siswa Kelas V SDN 2 Patarselamat

oleh siswa. Sehingga materi yang dipelajari akan dapat diterima dengan baik oleh siswa dan guru dapat memberikan dengan baik pula. Hal ini akan dapat terlaksana apabila guru dapat menyesuaikan dengan perkembangan jaman dalam menyampaikan materi dengan strategi belajar yang dapat meningkatkan kreativitas siswa juga. Sebab jika tidak dibarengi dengan pengetahuan guru yang baik, tidak menutup kemungkinan bahwa pengetahuan guru akan kalah dan tertinggal dari pengetahuan siswa. ${ }^{3}$

Artinya dengan menggunakan strategi pembelajaran yang benar akan mengarahkan siswa pada ketercapaian tujuan pendidikan yang dirumuskan. Sebagai contoh adalah mata pelajaran Pendidikan Kewarganegaraan untuk siswa kelas V SDN 2 Patarselamat tahun pelajaran 2017/2018. Ada beberapa temuan yang diperoleh oleh peneliti menunjukkan kurangnya partisipasi siswa dalam mengikuti pembelajaran. Guru cenderung aktif sedangkan siswanya pasif. Hal ini disebabkan oleh guru lebih senang menggunakan strategi pembelajaran konvensional seperti menerangkan materi sehingga siswa bosan. Kondisi ini menyebabkan prestasi belajar siswa sangat rendah.

Dewasa ini telah dikembangkan suatu pendekatan pembelajaran kooperatif untuk menghasilkan tujuan belajar yang baik. Mengapa harus kooperatif? Menurut Nurhadi "sejauh ini pendidikan di Indonesia masih didominasi oleh pandangan bahwa pengetahuan sebagai perangkat fakta-fakta yang harus dihafal". 4

Kelas masih berfokus pada guru sebagai sumber utama pengetahuan, kemudian ceramah menjadikan pilihan utama strategi belajar. Untuk itu diperlukan sebuah strategi baru yang lebih memberdayakan siswa. Sebuah strategi belajar yang tidak mengharuskan siswa menghafal fakta-fakta, tetapi sebuah strategi yang mendorong siswa mengkonstruksikan pengetahuan di benak mereka sendiri.

Kenyataan di lapangan pendidikan proses pencapaian pembelajaran di SDN 2 Patarselamat, masih menggunakan paradigma lama walaupun sekarang kurikulum telah berkembang. Sehingga tidak menutup kemungkinan hasil belajar yang dicapai oleh siswapun terkesan monoton, karena hanya menghafal suatu fakta dan guru dipandang sebagai sumber utama dalam belajar. Salah satu hasil belajar yang diperoleh adalah mata pelajaran Pendidikan Kewarganegaraan untuk kelas $\mathrm{V}$ menunjukkan hasil yang belum memenuhi ketuntasan secara klasikal. Dalam hal ini untuk pelajaran Pendidikan

${ }^{3}$ Kusaeri, Pembelajaran Aktif Reflektif dan Gaya Belajar (Yogyakarta : PT. Gavamedia, 2001), 96.

${ }^{4}$ Nurhadi, Metode Pembelajaran Efektif (Bandung : P.T Tarsito, 2002), 32. 
Kewarganegaraan SDN 2 Patarselamat menetapkan KKM sebesar 70. Sedangkan suatu kelas dinyatakan tuntas secara klasikal apabila jumlah siswa yang telah tuntas belajar secara individu mencapai $\geq 85 \%$.

Berdasarkan hal tersebut maka perlu ditetapkan metode pembelajaran yang sesuai pada setiap kompetensi dasar agar bisa memotivasi siswa dan meningkatkan pemahaman terhadap kesiapan dan ketuntasan belajar siswa di sekolah dasar. Berangkat dari masalah tersebut di atas maka penelitian tindakan kelas ini mengambil judul "Peningkatan Kemampuan Menjelaskan Pentingnya Keutuhan NKRI melalui Pembelajaran Talking Stick Siswa Kelas V SDN 2 Patarselamat".

\section{Kajian Pustaka}

\section{Prestasi Belajar}

a. Pengertian

Kemampuan intelektual siswa sangat menentukan keberhasilan siswa dalam memperoleh prestasi. Untuk mengetahui berhasil tidaknya seseorang dalam belajar maka perlu dilakukan suatu evaluasi, tujuannya untuk mengetahui prestasi yang diperoleh siswa setelah proses belajar mengajar berlangsung. Adapun prestasi dapat diartikan hasil diperoleh karena adanya aktivitas belajar yang telah dilakukan. Namun banyak orang beranggapan bahwa yang dimaksud dengan belajar adalah mencari ilmu dan menuntut ilmu. Ada lagi yang lebih khusus mengartikan bahwa belajar adalah menyerap pengetahuan. Belajar adalah perubahan yang terjadi dalam tingkah laku manusia. Proses tersebut tidak akan terjadi apabila tidak ada suatu yang mendorong pribadi yang bersangkutan.

Prestasi belajar merupakan hal yang tidak dapat dipisahkan dari kegiatan belajar, karena kegiatan belajar mengajar merupakan proses, sedangkan prestasi merupakan hasil dari proses belajar. Memahami pengertian prestasi belajar secara garis besar harus bertitik tolak kepada pengertian belajar itu sendiri. Untuk itu para ahli mengemukakan pendapatnya yang berbeda-beda sesuai dengan pandangan yang mereka anut. Namun dari pendapat yang berbeda itu dapat kita temukan satu titik persamaan.

Sehubungan dengan prestasi belajar, Purwanto memberikan pengertian prestasi belajar yaitu "hasil yang dicapai oleh seseorang dalam usaha belajar sebagaimana yang dinyatakan dalam rapor." 5

\footnotetext{
5 M. Ngalim Purwanto, Ilmu Pendidikan Teoritis dan Praktis, Edisi Kedua (Bandung : PT. Remaja
} Rosdakarya, 1995), 28. 
Peningkatan Kemampuan Menjelaskan Pentingnya Keutuhan NKRI

Melalui Pembelajaran Talking Stick Siswa Kelas V SDN 2 Patarselamat

Selanjutnya Winkel mengatakan bahwa "prestasi belajar adalah suatu bukti keberhasilan belajar atau kemampuan seseorang siswa dalam melakukan kegiatan belajarnya sesuai dengan bobot yang dicapainya." 6 Sedangkan menurut S. Nasution prestasi belajar adalah: "Kesempurnaan yang dicapai seseorang dalam berfikir, merasa dan berbuat. Prestasi belajar dikatakan sempurna apabila memenuhi tiga aspek yakni: kognitif, afektif dan psikomotor, sebaliknya dikatakan prestasi kurang memuaskan jika seseorang belum mampu memenuhi target dalam ketiga kriteria tersebut." 7

Berdasarkan pendapat di atas, maka dapat disimpulkan bahwa prestasi belajar merupakan tingkat kemanusiaan yang dimiliki siswa dalam menerima, menolak dan menilai informasi-informasi yang diperoleh dalam proses belajar mengajar. Prestasi belajar seseorang sesuai dengan tingkat keberhasilan sesuatu dalam mempelajari materi pelajaran yang dinyatakan dalam bentuk nilai atau rapor setiap bidang studi setelah mengalami proses belajar mengajar. Prestasi belajar siswa dapat diketahui setelah diadakan evaluasi. Hasil dari evaluasi dapat memperlihatkan tentang tinggi atau rendahnya prestasi belajar siswa. Dalam hal ini prestasi belajar yang dimaksud adalah kemampuan menjelaskan pentingnya keutuhan NKRI melalui pembelajaran Talking Stick siswa kelas V SDN 2 Patarselamat tahun pelajaran 2017/2018.

b. Faktor-faktor yang Mempengaruhi Prestasi Belajar

Proses pembelajaran akan berhasil manakala siswa mempunyai motivasi dalam belajar. Oleh sebab itu, guru perlu menumbuhkan motivasi belajar siswa, sehingga terbentuk perilaku belajar siswa yang efektif. Mengingat begitu kompleksnya masalah-masalah yang berkaitan dengan perilaku individu (siswa), baik yang terkait dengan faktor-faktor internal dari individu itu sendiri maupun keadaan eksternal yang mempengaruhinya.

Adapun faktor-faktor yang mendorong peningkatan prestasi belajar siswa adalah:

1) Faktor Intern (dari dalam siswa sendiri), meliputi:

1) Sikap terhadap belajar, 2) Motivasi belajar , 3) Konsentrasi belajar, 4)Mengolah bahan belajar, 5) Menyimpan pengolahan hasil belajar, 6) Menggali hasil belajar yang tersimpan, 7) Kemampuan berprestasi atau

${ }^{6}$ W.S. Winkel, Psikologi Pengajaran, (Yogyakarta : Gramedia, 1998), 162.

${ }^{7}$ S. Nasution, Metode Penelitian Naturulistik Kualitatif(Bandung : Penerbit Tarsito, 1988), 17. 
unjuk hasil kerja, 8) Rasa percaya diri siswa, 9) Intelegensi dan keberhasilan belajar, 10) Kebiasaan belajar, 11) Cita-cita siswa

2) Faktor Ekstern (dari luar siswa), meliputi:

Guru sebagai Pembina siswa belajar, 2) Sarana dan prasarana pembelajaran, 3) Kebijakan penilaian, 4) Lingkungan sosial siswa di sekolah, 5) Kurikulum di sekolah. ${ }^{8}$

Berdasarkan uraian di atas dapat disimpulkan bahwa prestasi belajar adalah hasil yang telah dicapai siswa dalam pembelajaran dengan didukung oleh dua faktor, baik faktor intern maupun ekstern.

\section{Metode Pembelajaran "Talking Stick"}

Metode pembelajaran merupakan suatu cara bagaimana proses belajar itu berlangsung. Pembelajaran harus memperhatikan minat dan kemampuan siswa. "Penggunaan metode yang tepat akan turut menentukan efektifitas dan efisiensi pembelajaran. Pembelajaran perlu dilakukan dengan sedikit ceramah dan metode-metode yang berpusat pada guru, serta lebih menekankan pada interaksi peserta didik. Penggunaan metode yang bervariasi akan sangat membantu peserta didik dalam mencapai tujuan belajar". 9

Metode pembelajaran Talking Stick ini merupakan salah satu metode pembelajaran yang dapat dikatakan menarik bagi siswa karena dalam pembelajaran ini siswa dapat belajar dengan serius tapi santai.

Model pembelajaran Talking Stick adalah suatu model pembelajaran kelompok dengan bantuan tongkat, kelompok yang memegang tongkat terlebih dahulu wajib menjawab pertanyaan dari guru setelah siswa mempelajari materi pokoknya, selanjutnya kegiatan tersebut diulang terusmenerus sampai semua kelompok mendapat giliran untuk menjawab pertanyaan dari guru.

Dalam penerapan model pembelajaran Kooperatif Tipe Talking Stick ini, guru membagi kelas menjadi kelompok-kelompok dengan anggota 5 atau 6 orang yang heterogen. Kelompok dibentuk dengan mempertimbangkan keakraban, persahabatan atau minat, yang dalam topik selanjutnya menyiapkan dan mempresentasikan laporannya kepada seluruh kelas.

Langkah-langkah yang dilakukan dalam metode "Talking Stick" sebagai berikut:

${ }^{8}$ Dimyati \& Mujiono, Teori Belajar Mengajar (Bandung: P.T Remaja Rosdakarya, 2006), 245-247.

${ }^{9}$ E. Mulyasa, Menjadi Guru Profesional (Bandung : PT Remaja Rosdakarya, 2005), 107. 
Peningkatan Kemampuan Menjelaskan Pentingnya Keutuhan NKRI

Melalui Pembelajaran Talking Stick Siswa Kelas V SDN 2 Patarselamat

1) Guru menyiapkan sebuah tongkat yang panjangnya $\pm 20 \mathrm{~cm}, 2)$ Guru menyampaikan materi pokok yang akan dipelajari, kemudian memberikan kesempatan para kelompok untuk membaca dan mempelajari materi pelajaran, 3) Siswa berdiskusi membahas masalah yang terdapat di dalam wacana, 4) Setelah siswa selesai membaca materi pelajaran dan mempelajari isinya, guru mempersilakan siswa untuk menutup isi bacaan, 5) Guru mengambil tongkat dan memberikan kepada salah satu siswa, setelah itu guru memberikan pertanyaan dan siswa yang memegang tongkat tersebut harus menjawabnya, demikian sampai sebagian besar siswa mendapat bagian untuk menjawab setiap pertanyaan dari guru, 6) Guru memberikan kesimpulan, 7) Guru memberikan evaluasi/penilaian, 8) Guru menutup pembelajaran.

\section{Proses Belajar Mengajar}

Pada hakikatnya dalam proses belajar mengajar terkandung kegiatan belajar yang dilakukan siswa dan mengajar dilakukan oleh guru. Menurut Tabrani Rusyan belajar adalah :

a. Belajar memperteguh prilaku melalui pengalaman, di dalam rumusan tersebut terkandung makna bahwa belajar merupakan suatu proses, suatu kegiatan, dan bukan hasil atau tujuan. Belajar bukan hanya mengingat, melainkan lebih luas dari itu yakni mengalami, hasil belajar bukan hanya penguasaan hasil latihan, melainkan perubahan perilaku.

b. Belajar adalah suatu proses perubahan tingkah laku individu melalui interaksi dengan lingkungan.

c. Belajar dalam arti yang luas ialah proses perubahan tingkah laku yang dinyatakan dalam bentuk penguasaan, penggunaan dan penilaian atau mengenai sikap dan nilai-nilai pengetahuan dan kecakapan dasar yang terdapat dalam berbagai bidang studi atau lebih luas lagi dalam berbagai aspek kehidupan atau pengalaman.

d. Belajar itu selalu menunjukkan suatu proses perubahan perilaku atau pribadi seseorang berdasarkan praktek atau pengalaman tertentu. ${ }^{10}$

Jadi, belajar itu pada prinsipnya adalah proses perubahan tingkah laku hanya cara dan tingkat pencapaiannya tidak sama. Sedangkan mengajar, menurut A. Tabrani Rusyan adalah :

10 Tabrani Rusyan dan Atang Kuswidja, Pendekatan dalam Proses Belajar Mengajar (Bandung : CV Remadja Karya, 1989), 7-9. 
a. Mengajar merupakan suatu proses yang kompleks, tidak sekadar menyampaikan informasi dari guru kepada siswa. Banyak kegiatan maupun tindakan yang harus dilakukan terutama bila diinginkan hasil belajar yang lebih baik pada seluruh siswa.

b. Mengajar adalah segala upaya yang sengaja dalam rangka memberikan kemungkinan bagi siswa untuk terjadinya proses belajar mengajar sesuai dengan tujuan yang telah dirumuskan. Sasaran akhir pada proses pengajaran adalah siswa belajar.

c. Menurut pandangan Willian H. Burton mengajar adalah upaya dalam memberikan rangsangan, bimbingan, pengarahan dan dorongan kepada siswa agar terjadi proses belajar.

d. Gane dan Brings menyatakan Instruction is a set of event wich affect barnes in such way that barning is facilitated. Jadi penting dalam mengajar bukan upaya guru menyampaikan bahan, melainkan bagaimana siswa dapat mempelajari bahan sesuai dengan tujuan. Hal ini berarti bahwa upaya guru hanya merupakan serangkaian peristiwa yang dapat mempengaruhi siswa belajar.

e. Mengajar dengan sukses harus berdasarkan atas pengakuan akan kebenaran bahwa pelajaran itu pada hakikatnya adalah suatu proses yang mengandung makna. ${ }^{11}$ (A. Jadi , mengajar sebagai aktivitas mengatur lingkungan sebaik-baiknya dan menghubungkan dengan kebutuhan siswa sehingga terjadi proses belajar pada diri siswa.

\section{Minat dan Motivasi Belajar}

Minat dan motivasi sangat berkaitan. Dengan motivasi akan tumbuh dorongan untuk melakukan sesuatu untuk mencapai tujuan dalam hal faktor ini adalah tujuan pembelajar. "Motivasi adalah salah satu faktor yang dapat meningkatkan kualitas pembelajaran, karena peserta didik akan belajar dengan sungguh-sungguh apabila memiliki motivasi yang tinggi". ${ }^{12}$

Sedangkan minat dapat diartikan sebagai kecenderungan seseorang untuk tertarik dalam menekuni bidang-bidang tertentu. Sebagaimana yang terjadi di sekolah, jika siswa tidak berminat pada mata pelajaran tertentu, maka tidak dapat diharapkan ia akan berhasil dengan baik dalam mengajar mata pelajaran tersebut dan jika sesuai dengan minatnya maka dapat diharapkan akan memperoleh hasil yang baik.

${ }^{11}$ Ibid., 26.

12 E. Mulyasa, Menjadi Guru Profesional, 174. 
Peningkatan Kemampuan Menjelaskan Pentingnya Keutuhan NKRI

Melalui Pembelajaran Talking Stick Siswa Kelas V SDN 2 Patarselamat

Setiap manusia ingin mengembangkan dirinya menjadi insan yang berpotensi dan berkualitas tentu mempunyai tujuan hidup yang diharapkan. Keinginan, harapan, cita-cita, hasrat, dan minat selalu mewarnai kehidupan yang selanjutnya akan mendorong seseorang untuk melakukan berbagai aktivitas dan akan meningkatkan kemampuan berfikir dan berkreasi. Minat adalah faktor yang penting dalam suatu usaha atau kegiatan manusia yang sangat subjektif, di mana minat sebagai aspek psikis manusia mempunyai potensi besar untuk mencapai tujuan tertentu.

Sedangkan As'ad menyatakan bahwa minat adalah sikap yang membuat senang akan objek situasi atau ide-ide tertentu, Hal ini diikuti oleh rasa senang dan kecenderungan untuk mencari objek yang disenangi itu. Pola-pola minat seseorang merupakan salah satu faktor yang menentukan kesesuaian orang dengan pekerjaannya. Minat orang terhadap jenis pekerjaan berbeda-beda. Tingkat prestasi kerja seseorang ditentukan oleh perpaduan antara minat dan bakat. ${ }^{13}$

Sukardi mengemukakan bahwa minat belajar adalah suatu kerangka mental yang terdiri dari kombinasi gerak perpaduan dan campuran dari perasaan, prasangka. ${ }^{14}$

Berdasarkan definisi di atas, maka dapat dikatakan bahwasanya ada kesamaan pendapat yang menetapkan minat sebagai gejala psikis. Dan pendapat-pendapat itu dapat ditentukan beberapa unsur yang mempengaruhi minat antara lain perhatian, kesadaran individu, kekuatan motif dan harapan serta perasaan senang yang membuat individu itu cenderung berhubungan lebih aktif lagi terhadap objek yang menjadi perhatiannya.

Minat secara umum diartikan sebagai suatu keadaan mental yang menghasilkan respons terarah pada situasi atau objek tertentu, yang menyenangkan dan memberikan objek kepuasan kepadanya. Dengan demikian minat dapat menimbulkan dan merupakan sikap yang menunjukkan suatu kesiapan berbuat bila ada situasi khusus yang sesuai dengan keadaan mental seseorang. Minat menyangkut aktivitas-aktivitas yang dipilih secara bebas oleh individu, Doyles Frayer dalam Nurkancana mengemukakan bahwa minat atau interes adalah gejala psikis yang berkaitan dengan objek atau aktivitas yang menstimulasi perasaan. Dengan demikian

${ }^{13}$ As'ad, Psikolodi Industri (Yogyakarta : Liberty, 1987), 4.

${ }^{14}$ Sukardi, Bimbingan dan Penyuluhan (Surabaya: Usaha Nasional, 1987), 25. 
minat senantiasa erat hubungannya dengan perasaan, individu, aktivitas, dan situasi. ${ }^{15}$

Sebab-Sebab Munculnya Minat. Minat seseorang ditinjau dari awal mulanya dapat dibedakan menjadi dua. Pertama minat yang berasal dari pembawaan, kedua minat yang muncul karena pengeruh dari luar. Minat sering tumbuh karena adanya bakat, yang merupakan aspek pembawaan, sehingga dapat disimpulkan bahwa minat tertentu berasal dari pembawaan. Minat juga dapat tumbuh melalui proses panjang karena pengaruh lingkungan dan kebutuhan.

Minat seseorang dapat pula tumbuh karena motif atau insentif. Perbuatan atau tingkah laku seseorang dapat didorong dengan memberi insentif -insentif. Berdasarkan ketahanan minat yang dibangkitkan oleh motif lebih kuat daripada minat yang dibangkitkan oleh insentif.

Ada tujuh ciri minat yang dikemukakan oleh Hurlock . Tujuh ciri-ciri tersebut adalah:

1) Minat tumbuh bersamaan dengan perkembangan fisik dan mental. Minat di semua bidang berubah selama terjadi perubahan fisik dan mental, 2) Minat bergantung pada persiapan belajar, seseorang tidak akan mempunyai minat sebelum mereka siap secara fisik dan mental, 3) Minat bergantung kepada kesempatan minat. Dengan bertumbuhnya lingkungan sosial seseorang menjadi terkait pada minat orang di luar yang mereka kenal, 4) Perkembangan minat mungkin terbatas. Ketidakmampuan fisik mental secara pengalaman sosial yang terbatas membatasi seseorang, 5) Minat dipengaruhi oleh pengaruh budaya yang ada pada sekitar orang tersebut hidup dan berinteraksi dengan masyarakat yang ada di sekelilingnya, 6) Minat berobot emosional. Bobot emosional aspek avektif dari minat menentukan kekuatan minat tersebut, 7) Minat dan egosentris. ${ }^{16}$

\section{Aspek-Aspek Minat}

Menurut Hurlock minat mempunyai dua aspek yaitu aspek kognitif dan aspek afektif. Aspek kognitif didasarkan pada konsep yang dikembangkan individu mengenai bidang yang berkaitan dengan minat. Karena minat cenderung egosentris aspek kognitif berdasarkan pada pernyataan apa saja keuntungan pribadi yang diperoleh dari minat itu. ${ }^{17}$

\footnotetext{
${ }_{15}$ Wayan Nurkancana, Evaluasi Pendidikan (Surabaya: Usaha Nasional, 1986), 229.

16 E. B. Hurlock, Psikologi Perkembangan: Suatu Pendekatan Sepanjang Rentang Kehidupan. Alih Bahasa: Soedjarwo dan Iswidayanti (Jakarta: Erlangga, 1990), 155.

17 Ibid. 16.
} 
Peningkatan Kemampuan Menjelaskan Pentingnya Keutuhan NKRI

Melalui Pembelajaran Talking Stick Siswa Kelas V SDN 2 Patarselamat

Konsep yang membangun aspek kognitif minat didasarkan atas pengalaman pribadi dan apa yang dipelajari di rumah, di sekolah, dan di masyarakat, serta berbagai jenis media masa. Aspek afektif atau bobot emosional konsep yang membangun aspek kognitif minat dinyatakan dengan sikap kegiatan yang ditimbulkan dari minat itu.

Seperti yang telah dikemukakan ke depan, minat secara umum diartikan sebagai suatu keadaan mental yang menghasilkan respons terarah kepada situasi atau objek tertentu yang menyenangkan dan memberikan kepuasan kepadanya. Dengan demikian minat dapat menumbuhkan dan merupakan sikap yang menunjukkan suatu kesiapan bila dan situasi khusus yang sesuai dengan keadaan mental seseorang.

Dari pendapat dan uraian di atas dikatakan bahwa aspek-aspek minat adalah aspek kognitif yang dekat dengan keadaan mental seseorang yang dapat menimbulkan respons terendah dan menimbulkan sikap yang sudah masuk pada aspek afektif.

\section{Pentingnya Pengukuran Minat}

Menurut Nurkancana terdapat beberapa alasan mengapa seorang guru perlu mengadakan pengukuran minat. Alasan tersebut adalah:

1) Untuk meningkatkan minat, 2) Memelihara Minat yang baru timbul, 3) Mencegah timbulnya minat terhadap hal-hal yang kurang baik, 4) Sebagai persiapan untuk memberikan bimbingan kepada anak tentang lanjutan studi atau pekerjaan yang cocok baginya. ${ }^{18}$

\section{Hasil Penelitian Dan Pembahasan}

Dalam penyajian hasil penelitian ini dapat dipaparkan dalam beberapa urutan penelitian ke dalam siklus-siklus.

\section{Siklus I}

\section{a. Tahap Perencanaan}

Dalam perencanaan penelitian tindakan kelas ini peneliti melakukan hal-hal sebagai berikut :

Menyusun rencana pelaksanaan / RP yang didalamnya memuat : 1) Guru menyiapkan sebuah tongkat yang panjangnya $\pm 10 \mathrm{~cm}, 2)$ Guru membagi kelas menjadi 2 kelompok beranggotakan 5 siswa, 3) Guru menyampaikan materi pokok yang akan dipelajari, kemudian memberikan kesempatan para kelompok untuk membaca dan

\footnotetext{
18 Wayan Nurkancana, Evaluasi Pendidikan, 230.
} 
mempelajari materi pelajaran, 4) Siswa berdiskusi membahas masalah yang terdapat di dalam wacana, 5) Setelah siswa selesai membaca materi pelajaran dan mempelajari isinya, guru mempersilakan siswa untuk menutup isi bacaan, 6) Guru mengambil tongkat dan memberikan kepada salah satu siswa, setelah itu guru memberikan pertanyaan dan siswa yang memegang tongkat tersebut harus menjawabnya, demikian sampai sebagian besar siswa mendapat bagian untuk menjawab setiap pertanyaan dari guru, 7) Semua kelompok diminta untuk mengungkapkan hasil pembahasannya dalam tanya jawab di kelas, 8) Guru memberikan kesimpulan, 9) Guru memberikan evaluasi/penilaian, 10) Guru menutup pembelajaran.

b. Tahap Pelaksanaan

Pada tahap ini menguraikan secara detail tentang realisasi proses pelaksanaan KBM dengan menggunakan metode Talking Stick. Pelaksanaan penelitian ini terbagi dalam dua siklus, yaitu seperti tertuang dalam siklus satu kemudian diulang sama persis di siklus kedua agar diperoleh hasil yang maksimal.

c. Tahap Pengamatan dan Evaluasi

Hasil Observasi Kegiatan Siswa Saat KBM Siklus 1

\begin{tabular}{|l|l|l|}
\hline No. & Kegiatan & Hasil \\
\hline 1. & $\begin{array}{l}\text { Antusias siswa dalam mengikuti jalannya proses } \\
\text { pembelajaran }\end{array}$ & Baik \\
\hline 2. & $\begin{array}{l}\text { Antusias siswa dalam melaksanakan tugas } \\
\text { kelompok sesuai dengan materi yang diperoleh }\end{array}$ & Cukup \\
\hline 3. & $\begin{array}{l}\text { Antusias siswa dalam mengikuti KBM dengan } \\
\text { menggunakan metode pembelajaran Talking } \\
\text { Stick }\end{array}$ & Baik \\
\hline 4. & $\begin{array}{l}\text { Ekspresi siswa yang mendapat tugas, utamanya } \\
\text { sebagai evaluator dan juru bicara saat berdiskusi } \\
\text { kelompok }\end{array}$ & Cukup \\
\hline 5. & $\begin{array}{l}\text { Keaktifan siswa di masing-masing kelompok } \\
\text { saat awal memahami materi }\end{array}$ & Kurang \\
\hline 6. & $\begin{array}{l}\text { Keaktifan siswa di masing-masing kelompok } \\
\text { ketika KBM berlangsung }\end{array}$ & Cukup \\
\hline 7. & $\begin{array}{l}\text { Keaktifan siswa di masing-masing kelompok } \\
\text { saat akhir KBM }\end{array}$ & Kurang \\
\hline 8. & $\begin{array}{l}\text { Tanggapan siswa terhadap KBM dengan } \\
\text { menggunakan metode Talking Stick }\end{array}$ & Cukup \\
\hline
\end{tabular}


Peningkatan Kemampuan Menjelaskan Pentingnya Keutuhan NKRI

Melalui Pembelajaran Talking Stick Siswa Kelas V SDN 2 Patarselamat

Data Angket untuk Siswa Siklus 1

\begin{tabular}{|c|c|c|c|}
\hline \multirow{2}{*}{ No. } & \multirow{2}{*}{ Pertanyaan } & \multicolumn{2}{|c|}{ Hasil } \\
\hline & & $\mathrm{Ya}$ & Tidak \\
\hline \multirow{2}{*}{1.} & \multirow{2}{*}{$\begin{array}{l}\text { Apakah pembelajaran dengan metode } \\
\text { Talking Stick menyenangkan? }\end{array}$} & 6 & 4 \\
\hline & & $60 \%$ & $40 \%$ \\
\hline \multirow{2}{*}{2.} & \multirow{2}{*}{$\begin{array}{l}\text { Apakah pembelajaran dengan metode } \\
\text { Talking Stick membuat kamu mudah } \\
\text { memahami materi? }\end{array}$} & 5 & 5 \\
\hline & & $50 \%$ & $50 \%$ \\
\hline \multirow{2}{*}{3.} & \multirow{2}{*}{$\begin{array}{l}\text { Apakah kamu senang menjadi ketua } \\
\text { kelompok, evaluator dan juru bicara saat } \\
\text { berdiskusi? }\end{array}$} & 6 & 4 \\
\hline & & $60 \%$ & $40 \%$ \\
\hline \multirow{2}{*}{4.} & \multirow{2}{*}{$\begin{array}{l}\text { Apakah kamu mengalami kesulitan } \\
\text { dalam menjalankan tugas sebagai ketua } \\
\text { kelompok, evaluator dan juru bicara? }\end{array}$} & 4 & 6 \\
\hline & & $40 \%$ & $60 \%$ \\
\hline \multirow[b]{2}{*}{5.} & \multirow{2}{*}{$\begin{array}{l}\text { Apakah kamu sudah mempelajari materi } \\
\text { yang akan didiskusikan dengan } \\
\text { kelompok? }\end{array}$} & 6 & 4 \\
\hline & & $60 \%$ & $40 \%$ \\
\hline \multirow[b]{2}{*}{6.} & \multirow{2}{*}{$\begin{array}{l}\text { Apakah kamu merasa kesulitan } \\
\text { menerangkan / mempresentasikan hasil } \\
\text { pekerjaan kamu di hadapan siswa dan } \\
\text { guru? }\end{array}$} & 5 & 5 \\
\hline & & $50 \%$ & $50 \%$ \\
\hline \multirow{2}{*}{7.} & \multirow{2}{*}{$\begin{array}{l}\text { Apakah kamu merasa kesulitan dalam } \\
\text { mengisi lembar penilaian siswa? }\end{array}$} & 7 & 3 \\
\hline & & $70 \%$ & $30 \%$ \\
\hline \multirow{2}{*}{8.} & \multirow{2}{*}{$\begin{array}{l}\text { Apakah kamu merasa kesulitan dalam } \\
\text { mengerjakan soal-soal posttest setelah } \\
\text { presentasi, berdiskusi dan setelah } \\
\text { mengisi lembar penilaian siswa? }\end{array}$} & 6 & 4 \\
\hline & & $60 \%$ & $40 \%$ \\
\hline
\end{tabular}

Hasil Penilaian Siklus I

$(\mathrm{KKM}=70)$

\begin{tabular}{|c|l|l|l|}
\hline No. & Nama Siswa & Nilai & Keterangan \\
\hline 1. & Aprilia Putri Yasmin & 80 & Tuntas \\
\hline 2. & Sasqiya Mega Utama & 70 & Tuntas \\
\hline 3. & Aditya Septianingrum & 60 & Remidi \\
\hline 4. & Alya Septika Maharani & 80 & Tuntas \\
\hline 5. & Alyssa Nabila Putri P. & 70 & Tuntas \\
\hline 6. & Ananda Yudha Pratama & 60 & Remidi \\
\hline 7. & Andhika Bagus Permana & 70 & Tuntas \\
\hline 8. & Audri Adelia Muflikah & 80 & Tuntas \\
\hline
\end{tabular}




\begin{tabular}{|c|c|l|l|}
\hline 9. & Cantika Anggun Septiani & 70 & Tuntas \\
\hline 10. & Deanova Indra Gunawan & 60 & Remidi \\
\hline & Jumlah & $\mathbf{7 0 0}$ & \\
\hline & Rata-Rata & $\mathbf{7 0}$ & \\
\hline
\end{tabular}

Hasil rata-rata prestasi belajar $=\frac{700}{10}=70$

Ketuntasan belajar siswa $\quad=\frac{7}{10} \times 100 \%=70 \%$

Dari tabel di atas dapat dijelaskan bahwa melalui pembelajaran Talking Stick diperoleh hasil rata-rata prestasi belajar siswa adalah $\mathbf{7 0}$ dan ketuntasan belajar baru mencapai $\mathbf{7 0 \%}$ atau ada 7 siswa dari 10 siswa sudah tuntas belajar. Pada siklus I secara klasikal siswa belum tuntas belajar, karena siswa yang memperoleh nilai $\geq 70$ sebesar $\mathbf{7 0} \%$ lebih kecil dari persentase ketuntasan yang dikehendaki yaitu sebesar $85 \%$.

d. Tahap Refleksi

Melihat hasil pengamatan dari tabel nilai siswa, baik sebelum dan sesudah siklus I berlangsung sesuai dengan ketentuan (waktu maupun tingkat ketuntasannya).

Kondisi yang dapat dianalisa dari proses pelaksanaan KBM dengan metode pembelajaran Talking Stick, maka dapat diberikan beberapa poin stressing antara lain :

1) Persiapan materi

Dalam mempersiapkan materi untuk pelaksanaan siklus I cakupan materi banyak dan luas. Artinya pembagian materi yang disesuaikan dengan $\mathrm{KD}$ masing-masing kelompok terlalu banyak sehingga menjadikan kesulitan tersendiri bagi siswa untuk memahaminya dalam waktu relative singkat. Untuk guru PKn perlu memperhatikan hal ini pada pelaksanaan siklus berikutnya.

2) Pelaksanaan KBM

Dalam pelaksanaan KBM, siswa dibagi menjadi 4 kelompok yang ditentukan oleh guru. Adapun pembagian kelompok ini kurang memperhatikan tingkat kemampuan, keaktifan, sikap dari masingmasing siswa, sehingga dalam proses KBM dijumpai kelompok yang aktif dan kelompok yang pasif, hal ini dapat menjadi hambatan untuk mencapai ketuntasan belajar siswa.

3) Dari hasil pengamatan awal siklus I ditinjau dari segi pemahaman materi siswa dirasa kurang, tampak dari nilai rata-rata siswa 70 dan ketuntasan belajar baru mencapai 70\%. Untuk mencapai kompetensi 
Peningkatan Kemampuan Menjelaskan Pentingnya Keutuhan NKRI

Melalui Pembelajaran Talking Stick Siswa Kelas V SDN 2 Patarselamat

yang sesungguhnya maka masih perlu pelaksanaan penelitian pada siklus berikutnya.

\section{Siklus 2}

a. Tahap Perencanaan

Pada tahap perencanaan siklus 2 pada dasarnya sama dengan siklus 1, ada perbedaan sedikit dalam pembagian kelompok. Pada siklus 1 dibentuk menjadi 2 kelompok, pada siklus 2 dibuat 3 kelompok.

b. Tahap Pelaksanaan

Pada tahap ini menguraikan secara detail tentang realisasi proses pelaksanaan KBM dengan menggunakan metode Talking Stick. Pelaksanaan penelitian ini terbagi dalam dua siklus, yaitu seperti tertuang dalam siklus satu kemudian diulang sama pada siklus kedua agar diperoleh hasil yang maksimal.

c. Tahap Pengamatan dan Evaluasi

Pada tahap ini guru mengadakan pengamatan dan evaluasi terhadap siswa selama proses pembelajaran berlangsung pada siklus satu, maka diperoleh hasil-hasil sebagai berikut :

Hasil Observasi Kegiatan Siswa Saat KBM Siklus II

\begin{tabular}{|l|l|l|}
\hline No. & Kegiatan & Hasil \\
\hline 1. & $\begin{array}{l}\text { Antusias siswa dalam mengikuti jalannya proses } \\
\text { pembelajaran }\end{array}$ & Baik \\
\hline 2. & $\begin{array}{l}\text { Antusias siswa dalam melaksanakan tugas } \\
\text { kelompok sesuai dengan materi yang diperoleh }\end{array}$ & Baik \\
\hline 3. & $\begin{array}{l}\text { Antusias siswa dalam mengikuti KBM dengan } \\
\text { menggunakan metode pembelajaran Talking Stick }\end{array}$ & Baik \\
\hline 4. & $\begin{array}{l}\text { Ekspresi siswa yang mendapat tugas, utamanya } \\
\text { sebagai evaluator dan juru bicara saat berdiskusi } \\
\text { kelompok }\end{array}$ & Baik \\
\hline 5. & $\begin{array}{l}\text { Keaktifan siswa di masing-masing kelompok saat } \\
\text { awal memahami materi }\end{array}$ & Cukup \\
\hline 6. & $\begin{array}{l}\text { Keaktifan siswa di masing-masing kelompok } \\
\text { ketika KBM berlangsung }\end{array}$ & Baik \\
\hline 7. & $\begin{array}{l}\text { Keaktifan siswa di masing-masing kelompok saat } \\
\text { akhir KBM }\end{array}$ & Cukup \\
\hline 8. & $\begin{array}{l}\text { Tanggapan siswa terhadap KBM dengan } \\
\text { menggunakan metode Talking Stick }\end{array}$ & Baik \\
\hline
\end{tabular}


Data Angket untuk Siswa Siklus II

\begin{tabular}{|c|c|c|c|}
\hline \multirow{2}{*}{ No. } & \multirow{2}{*}{ Pertanyaan } & \multicolumn{2}{|c|}{ Hasil } \\
\hline & & $\mathbf{Y a}$ & Tidak \\
\hline \multirow{2}{*}{1.} & \multirow{2}{*}{$\begin{array}{l}\text { Apakah pembelajaran dengan metode } \\
\text { Talking Stick menyenangkan? }\end{array}$} & 8 & 2 \\
\hline & & $80 \%$ & $20 \%$ \\
\hline \multirow{2}{*}{2.} & \multirow{2}{*}{$\begin{array}{l}\text { Apakah pembelajaran dengan metode } \\
\text { Talking Stick membuat kamu mudah } \\
\text { memahami materi? }\end{array}$} & 6 & 4 \\
\hline & & $60 \%$ & $40 \%$ \\
\hline \multirow{2}{*}{3.} & \multirow{2}{*}{$\begin{array}{l}\text { Apakah kamu senang menjadi ketua } \\
\text { kelompok, evaluator dan juru bicara saat } \\
\text { berdiskusi? }\end{array}$} & 7 & 3 \\
\hline & & $70 \%$ & $30 \%$ \\
\hline \multirow{2}{*}{4.} & \multirow{2}{*}{$\begin{array}{l}\text { Apakah kamu mengalami kesulitan dalam } \\
\text { menjalankan tugas sebagai ketua } \\
\text { kelompok, evaluator dan juru bicara? }\end{array}$} & 6 & 4 \\
\hline & & $60 \%$ & $40 \%$ \\
\hline \multirow{2}{*}{5.} & \multirow{2}{*}{$\begin{array}{l}\text { Apakah kamu sudah mempelajari materi } \\
\text { yang akan didiskusikan dengan kelompok? }\end{array}$} & 8 & 2 \\
\hline & & $80 \%$ & $20 \%$ \\
\hline \multirow[b]{2}{*}{6.} & \multirow{2}{*}{$\begin{array}{l}\text { Apakah kamu merasa kesulitan } \\
\text { menerangkan / mempresentasikan hasil } \\
\text { pekerjaan kamu di hadapan siswa dan } \\
\text { guru? }\end{array}$} & 6 & 4 \\
\hline & & $60 \%$ & $40 \%$ \\
\hline \multirow{2}{*}{7.} & \multirow{2}{*}{$\begin{array}{l}\text { Apakah kamu merasa kesulitan dalam } \\
\text { mengisi lembar penilaian siswa? }\end{array}$} & 7 & 3 \\
\hline & & $70 \%$ & $30 \%$ \\
\hline \multirow{2}{*}{8.} & \multirow{2}{*}{$\begin{array}{l}\text { Apakah kamu merasa kesulitan dalam } \\
\text { mengerjakan soal-soal posttest setelah } \\
\text { presentasi, berdiskusi dan setelah mengisi } \\
\text { lembar penilaian siswa? }\end{array}$} & 8 & 2 \\
\hline & & $80 \%$ & $20 \%$ \\
\hline
\end{tabular}

Hasil Penilaian Siklus II

$$
(\mathrm{KKM}=70)
$$

\begin{tabular}{|c|l|l|l|}
\hline No. & Nama Siswa & Nilai & Keterangan \\
\hline 1. & Aprilia Putri Yasmin & 90 & Tuntas \\
\hline 2. & Sasqiya Mega Utama & 80 & Tuntas \\
\hline 3. & Aditya Septianingrum & 70 & Tuntas \\
\hline 4. & Alya Septika Maharani & 100 & Tuntas \\
\hline 5. & Alyssa Nabila Putri P. & 80 & Tuntas \\
\hline 6. & Ananda Yudha Pratama & 80 & Tuntas \\
\hline 7. & Andhika Bagus Permana & 70 & Tuntas \\
\hline
\end{tabular}


Peningkatan Kemampuan Menjelaskan Pentingnya Keutuhan NKRI

Melalui Pembelajaran Talking Stick Siswa Kelas V SDN 2 Patarselamat

\begin{tabular}{|c|l|l|l|}
\hline 8. & Audri Adelia Muflikah & 90 & Tuntas \\
\hline 9. & Cantika Anggun Septiani & 90 & Tuntas \\
\hline 10. & Deanova Indra Gunawan & 70 & Tuntas \\
\hline & Jumlah & $\mathbf{8 2 0}$ & \\
\hline & Rata-Rata & $\mathbf{8 2}$ & \\
\hline
\end{tabular}

Hasil rata-rata prestasi belajar $=\frac{820}{10}=82$

Ketuntasan belajar siswa $\quad=\frac{10}{10} \times 100 \%=100 \%$

Dari tabel di atas dapat dijelaskan bahwa melalui pembelajaran Talking Stick diperoleh hasil rata-rata prestasi belajar siswa mengalami peningkatan pada siklus kedua yaitu 82 , dan ketuntasan belajar mencapai $100 \%$ atau ada semua siswa sudah tuntas belajar. Pada siklus II secara klasikal siswa sudah tuntas belajar.

d. Tahap Refleksi

Melihat hasil pengamatan dari tabel nilai siswa, baik sebelum dan sesudah siklus 2 berlangsung sesuai dengan ketentuan (waktu maupun tingkat ketuntasannya).

Kondisi yang dapat dianalisa dari Proses pelaksanaan KBM dengan metode pembelajaran Talking Stick, maka dapat diberikan beberapa poin stressing antara lain :

1) Persiapan materi

Dalam mempersiapkan materi untuk pelaksanaan siklus 2 cakupan materi telah dipersempit. Soal yang diberikan pada siswa dapat diselesaikan dengan waktu yang telah ditentukan.

2) Pelaksanaan KBM

Karena dengan anggota kelompok 5 orang dianggap kurang efektif maka pada siklus 2 dijadikan menjadi 3 kelompok dengan anggota kelompok 3 orang. Pembagian kelompok telah disesuaikan dengan hasil tes siklus kedua.

Dari hasil pengamatan awal siklus 2 ditinjau dari segi pemahaman materi siswa dirasa sudah cukup baik dan nilai rata-rata telah mengalami peningkatan dari siklus I yaitu 82 dan ketuntasan belajar mencapai $\mathbf{1 0 0 \%}$.

Berdasarkan hasil pengamatan dan analisa selanjutnya dicatat dalam instrumen-instrumen penilaian, maka dimulai dari siklus I, kegiatan siswa pada saat KBM dengan metode pembelajaran Talking Stick, antusias siswa 
secara umum baik, namun siswa yang mendapat tugas sebagai juru bicara kelompok masih merasa terbebani sehingga ekspresi siswa tersebut kurang baik, keaktifan siswa di intern kelompok cukup, bahkan cenderung pasif.

Untuk memberi gambaran maka penulis menyajikan perbandingan dari hasil kedua siklus tersebut sebagai berikut:

Perbandingan Rata-rata dan Persentase Ketuntasan

\begin{tabular}{|l|l|l|}
\hline & Siklus I & Siklus II \\
\hline Nilai Rata-rata & 70 & 82 \\
\hline $\begin{array}{l}\text { Persentase } \\
\text { Ketuntasan }\end{array}$ & $70 \%$ & $100 \%$ \\
\hline
\end{tabular}

Untuk lebih jelasnya peningkatan hasil belajar siswa tersebut, maka penulis atau peneliti menunjukkannya melalui diagram perbandingan nilai rata-rata dan persentase ketuntasan hasil belajar siswa dari setiap siklusnya berikut ini :

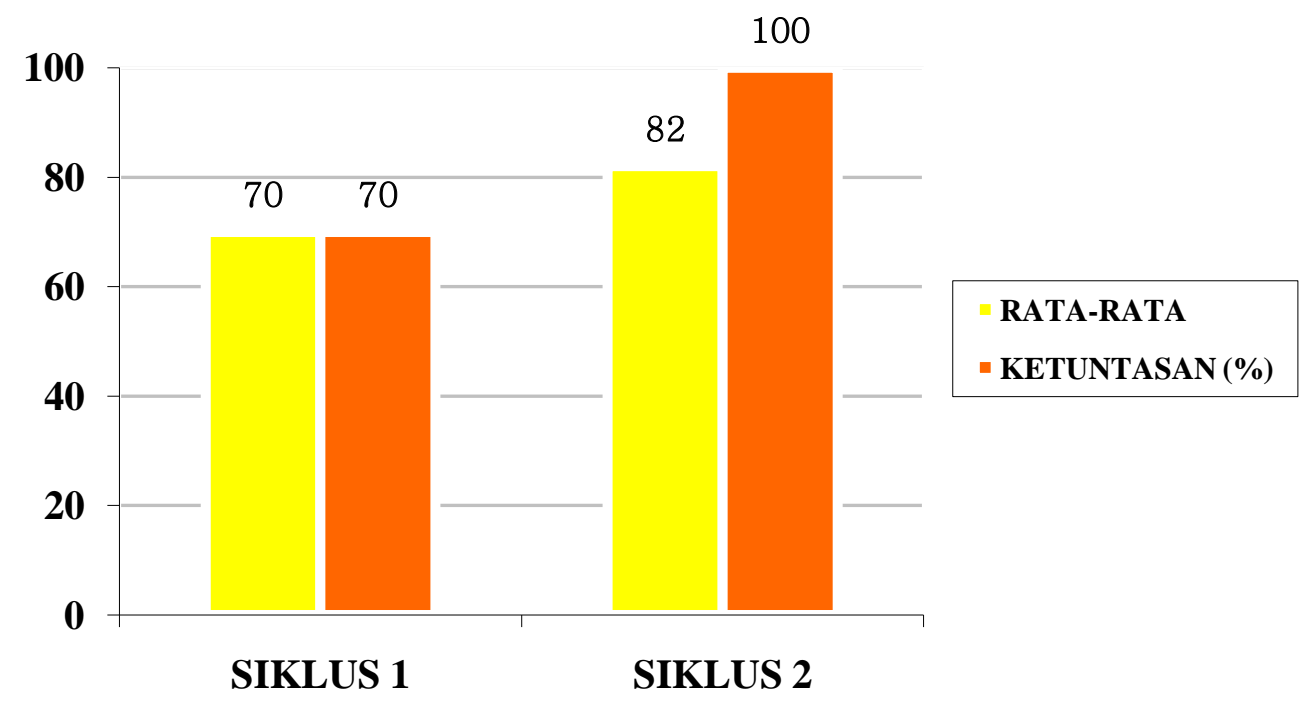

Diagram Rata-rata dan Ketuntasan tiap Siklus

Dari hasil analisis dan observasi adanya peningkatan pada setiap siklus, maka dapat disimpulkan ada peningkatan kemampuan menjelaskan pentingnya keutuhan NKRI melalui pembelajaran Talking Stick siswa kelas V SDN 2 Patarselamat tahun pelajaran 2017/2018.

\section{Kesimpulan dan Saran}

Dari uraian pada bab terdahulu, maka dapat penulis simpulkan penelitian tindakan kelas ini sebagai berikut:

1. Metode pembelajaran Talking Stick menjadikan siswa lebih aktif dan meningkatkan minat, sikap serta kerja sama siswa dalam proses 
Peningkatan Kemampuan Menjelaskan Pentingnya Keutuhan NKRI

Melalui Pembelajaran Talking Stick Siswa Kelas V SDN 2 Patarselamat

pembelajaran khususnya dalam memahami materi mata pelajaran PKn pada kompetensi dasar menjelaskan pentingnya keutuhan NKRI.

2. Dengan penggunaan metode Talking Stick memberikan suasana yang menyenangkan bagi siswa, hal ini terlihat dari antusias siswa dalam mengikuti proses pembelajaran

3. Dengan keaktifan siswa dan suasana yang menyenangkan saat pembelajaran PKn pada kompetensi dasar menjelaskan pentingnya keutuhan NKRI, sehingga hasil belajar / tes semakin meningkat dari siklus ke siklus yaitu nilai rata-rata pada siklus I 70 dan ketuntasan belajar 70\% dan pada siklus II mengalami peningkatan yaitu 82 dan ketuntasan belajar 100\%. Hal ini menunjukkan adanya pengaruh positif antara peningkatan minat dan sikap dan kerja sama terhadap nilai ulangan siswa

Dari kesimpulan yang didapatkan, maka penulis memberikan saran sebagai berikut:

1. Penelitian tindakan kelas ini bisa ditindak lanjuti oleh peneliti atau guru untuk semua mata pelajaran

2. Metode Talking Stick dalam penelitian ini dapat dijadikan sebagai alternatif metode pembelajaran PKn.

3. Jika metode Talking Stick digunakan dalam pembelajaran, sebaiknya siswa yang berperan sebagai ketua kelompok disiapkan dengan dibuatkan rangkuman yang spesifik terhadap materi sehingga terarah sebelum proses belajar untuk berdiskusi. Siswa dituntut dan diarahkan untuk mampu memahami lebih dulu materi yang diberikan sebelum didiskusikan di kelompok. Sehingga diperlukan waktu khusus untuk membimbingnya.

\section{Daftar Pustaka}

As'ad. Psikolodi Industri. Yogyakarta : Liberty. 1987.

Dimyati \& Mujiono. Teori Belajar Mengajar. Bandung: P.T Remaja Rosdakarya. 2006.

Hamalik, O. Proses Belajar Mengajar. Jakarta : PT. Bumi Aksara. 2001.

Hurlock., E. B. Psikologi Perkembangan: Suatu Pendekatan Sepanjang Rentang Kehidupan. Alih Bahasa: Soedjarwo dan Iswidayanti. Jakarta: Erlangga. 1990.

Kusaeri. Pembelajaran Aktif Reflektif dan Gaya Belajar. Yogyakarta : PT. Gavamedia. 2001.

Mulyasa, E. Menjadi Guru Profesional. Bandung : PT Remaja Rosdakarya. 2005.

Nasution, S. Metode Penelitian Naturulistik Kualitatif. Bandung : Penerbit Tarsito. 1988. 
Maria Ulfa

Nurhadi. Metode Pembelajaran Efektif. Bandung : P.T Tarsito. 2002.

Nurkancana, Wayan. Evaluasi Pendidikan. Surabaya: Usaha Nasional. 1986.

Purwanto, M. Ngalim. Ilmu Pendidikan Teoritis dan Praktis. Edisi Kedua.

Bandung : P'T. Remaja Rosdakarya. 1995.

Rusyan, Tabrani dan Atang Kuswidja. Pendekatan dalam Proses Belajar Mengajar.

Bandung: CV Remadja Karya. 1989.

Sukardi. Bimbingan dan Penyuluhan. Surabaya: Usaha Nasional. 1987.

Usman. Proses Belajar Mengajar. Jakarta: Prestasi Pustaka Raya. 2002.

Winkel, W.S. Psikologi Pengajaran. Yogyakarta : Gramedia. 1998. 